79 巻 802 号 2013 6)

\title{
摂動法を用いた粒子強化複合材料の確率均質化逆解析*
}

坂田 誠一郎 ${ }^{* 1}$, 清水 義隆*2

\section{Inverse Stochastic Homogenization Analysis for a Particle-Reinforced Composite Material with the Perturbation-Based Approach}

\author{
Sei-ichiro SAKATA*1 and Yoshitaka SHIMIZU \\ ${ }^{* 1}$ Kinki Univ. Dept. of Mechanical Engineering \\ Kowakae 3-4-1, Higashi-Osaka, Osaka, 577-8502, Japan
}

This paper discusses the inverse stochastic homogenization analysis for a particle-reinforced composite material. The homogenization analysis is performed with the homogenization theory, and the stochastic analysis is performed with the perturbation-based approach. In order to analyze the inverse stochastic homogenization problem, which aims to identify the coefficient of variances of the randomly varied elastic properties of component materials from the probabilistic characteristics of the homogenized elastic properties, the inverse stochastic homogenization method with the perturbation-based technique is proposed. The probabilistic properties of the homogenized elastic properties, which are obtained from an experiment or the Monte-Carlo simulation, are assumed to be known and used in the inverse stochastic homogenization analysis. The inverse stochastic homogenization problems with considering a single- or multi-variation of the elastic properties of the component materials are solved, and from the numerical results, accuracy and effectiveness of the proposed method are discussed.

Key Words : Inverse Stochastic Homogenization Analysis, Stochastic Homogenization Analysis, Perturbation, Particle-Reinforced Composite Material, Microscopic Random Variation

\section{1. 緒言}

複合材料は, 二種類以上の素材を組み合わせた材料であり，高比岡性などの特長から構造材料として広く利用 されている．しかし，均質材料と比べて微視構造が複杂隹であり，複合材料を構成する素材の物性值や形状等のば らつきが, 複合材料全体の巨視的な力学特性や微視的な応力状態に複雑な影響を及ぼす場合がある. 弚のため， 複合材料を用いた構造物の信頼性評価の際に注意する必要がある.この観点から，近年では複合材料を構成する 素材のばらつき (微視的なばらつき) が, 複合材料の平均的な材料特性のばらつきや微視的な応力状態に及ぼす 影響を調査した報告が見られるようになった .

これらの先行研究として, Kaminski ら ${ }^{(1)(2) や S a k a t a ~ ら ~}{ }^{(3)(4)(5)}$ は一方向繊維強化複合材料や粒子強化複合材料につ いて, 素材の物性値の微視的なばらつきが複合材料の平均的な材料特性に及ぼす影響を解析する確率均質化解析 について報告した . また , Sakata らは複合材料の微視的な物性值のばらつきが微視的な応力状態に及ぼす影響を 解析するマルチスケール確率応力解析について報告した ${ }^{(6)(7)}$.このように, 先行研究では微視的な物性值のばらつ きを仮定し，巨視的な材料特性のばらつきや微視的な応力状態のばらつきに及ぼす影響の解析が行われている．

しかし，現実問題における複合材料の微視的な物性值のばらつきは，素材弚のものがもともと有するものだけ でなく，例えば複合材料の射出成形など加圧加熱過程を伴う製造工程で受ける力学的や熱的，もしくは化学的影 響など製造工程に起因する場合もある．また，経年劣化等の後天的な条件に起因する微視的なばらつきも存在す

* 原稿受付 2012 年 12 月 13 日

${ }^{* 1}$ 正員, 近畿大学（干577-8502 大阪府東大阪市小若江 3-4-1)

*2 島根大学大学院 総合理工学研究科

E-mail: sakata@mech.kindai.ac.jp 
る.これらの影響は一般に複雑であるとともに，製造工程を経た後の複合材料内部における構成材料単独の物性 値を測定することは困難であると考えられる．したがって，このような微視的なばらつきが末知の場合には，実 際に測定可能な複合材料の平均材料特性の巨視的なばらつき量から，微視的な物性値のばらつき量を推定する解 析が必要となる.

これらの背景に対し, Sakata らは複合材料の平均的材料特性のばらつき量 (分散もしくは変動係数) から微視 的なばらつき（例えば素材の材料定数の分散もしくは変動係数）を推定する解析を確率均質化逆解析と名付け， 等価弾性特性解析手法に Mori-Tanaka の手法 ${ }^{(8)}$, 確率特性解析手法にモンテカルロシミュレーションを用いた確率 均質化逆解析手法を提案した ${ }^{(9)}$. しかしながら，Mori-Tanaka の手法は複杂倠な微視構造を考慮することか難しく微 視的な応力状態も精確に解析できないという問題点を有する .一方, 解析手法に例えば均質化法 ${ }^{(10)}$ を用いた場合， モンテカルロシミュレーションを用いた確率均質化逆解析は高い計算コストを要するという問題が生じる . 乥こ で, 本報では複合材料の等価弾性特性解析手法として均質化法, 確率特性解析手法として摂動法に基づく手法を 用いた確率均質化逆解析手法を提案する .决て,ガラス粒子強化複合材料を例として確率均質化逆解析を試み, 提案手法の有効性を調査したので報告する。

\section{2. 確率均質化解析と確率均質化逆解析の概要}

確率均質化解析とは, 複合材料における素材の物性値や微視構造のばらつきの種類や大きさから複合材料の等 価弾性特性のばらつきの大きさを求める解析である.これとは逆に, 確率均質化逆解析とは, 複合材料の等価弾 性定数のばらつきの大きさからから素材の物性値などの微視的なばらつきの大きさを推定する解析である . 図 1 に，本報における確率均質化解析と確率均質化逆解析の概略を示す . 图 1 の $E_{p}$ と $E_{m}$ は強化材および母材の縦弾 性定数， $v_{m}$ は母材のポアソン比， $E^{e q}, G^{e q}, v^{e q}$ は光れ艺れ巨視スケールにおける等価縦弾性定数，せん断 弾性定数およびポアソン比を表す．本報では，微視的なばらつきとして複合材料を構成する素材の弾性定数のば らつきを考え，図 1 下側の確率均質化逆解析に，摂動法に基づく確率均質化法を用いる点が特徵である .

なお，本報で述べる確率均質化逆解析は，微視的なばらつき量の推定を目的とするが，例えば既報のマルチス ケール確率応力解析 ${ }^{(6)(7)}$ のように,ミクロなばらつき量とマクロなばらつき量の両者か既知である必要がある解析 を実施するためにも有用である .

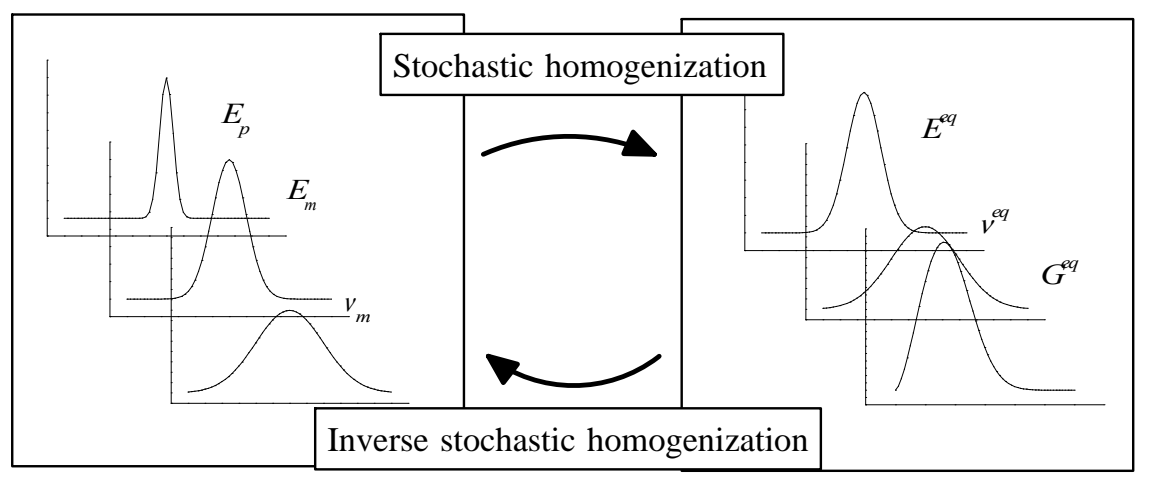

Microscopic random variables

Macroscopic random properties

Fig.1 Schematic view of the stochastic homogenization and inverse stochastic homogenization problems

一般に，複合材料の等価弾性定数は実験等により測定できることから，光の確率特性も実験を利用した補助的 な計算により推定できる.しかし，等価弾性定数のばらつきの要因は多数想定でき，乥れ光れが複雑な影響を及 ぼすと考えられる．これに対し本研究では，上記の逆解析の精度調査のため，順問題 (確率均質化問題) におけ る入力パラメータの実際のばらつきが明らかである必要があることから，素材の弾性定数のばらつきを仮定した 確率均質化解析による擬似的な数値実験をモンテカルロシミュレーションにより行い，乥こで得られた等価弾性 定数の確率特性を既知として素材の弾性定数のばらつきの大きさを推定する問題設定とした . 


\section{3. 解析手法}

\section{$3 \cdot 1$ 均質化法}

複合材料を構成する微視的な物性值(素材の物性値)から，複合材料全体の巨視的な平均材料定数(等価弾性定数) を求める問題を均質化問題と呼ぶ . 一般的な等価弾性特性解析手法として, 古典的複合則 , Eshelby の等価介在 物法および光れを拡張した Mori-Tanaka の手法 , 均質化法等か学げられる . 光の中でも均質化法は, 微視構造と 巨視構造の支配方程式間の数学的整合性が高く，三次元的に複杂倠な微視構造を解析することができるという長所 がある.また，巨視的状態 (マクロひずみ場) を考慮し微視的な応力場を解析対象とするマルチスケール応力解 析を実行することができる . 以上の利点を鑑み, 本報では等価弾性特性解析手法として均質化法を用いる .

均質化法では，非常に小さなスケール内に不均質かつ周期的な構造を持った材料を巨視的に均質体とみなし， 兴の平均的特性を計算する. 図 2 に周期的な微視構造を有する粒子強化複合材料の概略図を示す.

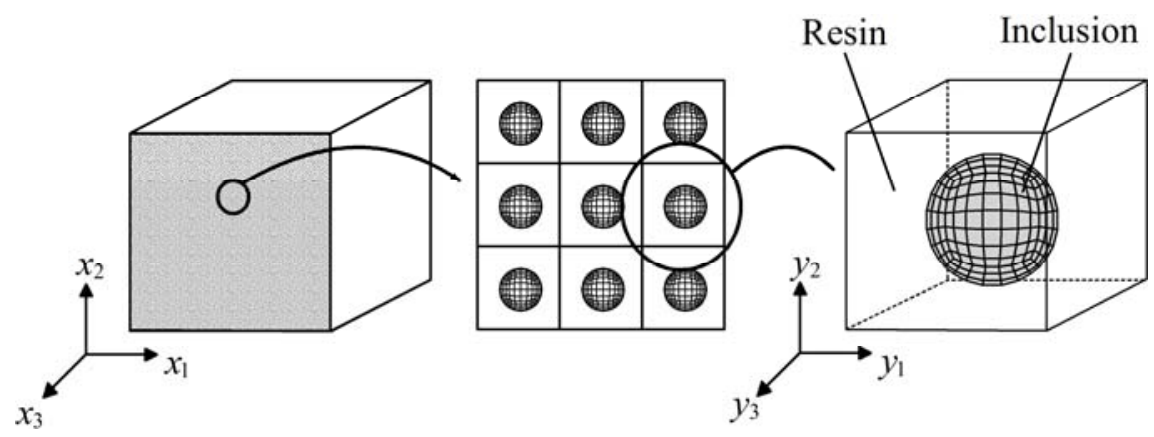

$\begin{array}{lll}\text { (a) Macrostructure } & \text { (b) Periodic microstructure } & \text { (c) Microstructure }\end{array}$

Fig.2 Schematic view of a glass particle reinforced composite material

均質化法を用いた場合，均質化された巨視的弾性テンソル $\boldsymbol{C}^{H}$ は次式より求めることができる .

$$
\boldsymbol{C}^{H}=\frac{1}{|Y|} \int_{Y} \boldsymbol{C}\left(\boldsymbol{I}-\frac{\partial \chi}{\partial \boldsymbol{y}}\right) \mathrm{d} \boldsymbol{y}
$$

ただし, $|Y|$ は微視的なユニットセルの体積， $\boldsymbol{C}$ は微視的なユニットセル中の各素材の弾性テンソル， $\boldsymbol{I}$ は単位テ ンソル, $\boldsymbol{\chi}$ は特性変位, $\boldsymbol{y}$ は微視構造の座標変数, $\mathrm{d} \boldsymbol{y}$ は微視構造における微小要素, 上添え字 $H$ は均質化され た量を表す .また , $\chi$ は次式の特性方程式より求めることができる.

$$
\int_{Y} \frac{\partial}{\partial \boldsymbol{y}} \boldsymbol{C} \frac{\partial \chi}{\partial \boldsymbol{y}} \mathrm{d} y=\int_{Y} \frac{\partial}{\partial \boldsymbol{y}} \boldsymbol{C} \mathrm{d} \boldsymbol{y}
$$

ここで複合材料の素材の弾性定数か確率変動を有する場合, 均質化された巨視的弾性テンソルの実現值 $\boldsymbol{C}^{H^{*}}$ は 次式より求めることができる .

$$
\boldsymbol{C}^{H^{*}}=\frac{1}{|Y|} \int_{Y} \boldsymbol{C}^{*}\left(\boldsymbol{I}-\frac{\partial \boldsymbol{X}^{*}}{\partial \boldsymbol{y}}\right) \mathrm{d} \boldsymbol{y}
$$

ただし, 上添え字*は確率変数もしくは確率応答の実現值を表す．ここで素材の弾性定数の実現値が, 弚の期待 值及び正規化された確率変数により表現できると仮定する．このとき，例えば素材の縦弾性定数の実現值は次式 で表現できる .ただし上添え字 0 は期待值， $\alpha$ は正規分布に従う正規化された確率変数である .

$$
E^{*}=E^{0}\left(1+\alpha^{*}\right)
$$

このとき, 式(2)の特性方程式は次式となる .

$$
\int_{Y} \frac{\partial}{\partial \boldsymbol{y}} \boldsymbol{C}\left(\alpha^{*}\right) \frac{\partial \chi^{*}}{\partial \boldsymbol{y}} \mathrm{d} y=\int_{Y} \frac{\partial}{\partial \boldsymbol{y}} \boldsymbol{C}\left(\alpha^{*}\right) \mathrm{d} \boldsymbol{y}
$$

この方程式の解 $\chi *$ および $\boldsymbol{C}^{*}=\boldsymbol{C}\left(\alpha^{*}\right)$, 式(3)を用いることで , 等価弾性テンソルの実現值 $\boldsymbol{C}^{H^{*}}$ か計算できる . ま た, 正方配列の微視構造を有する粒子強化複合材料の場合, 等価なヤンク率 $E^{e q}$, 等価な横弾性定数 $G^{e q}$ 及び等 価なポアソン比 $v^{e q}$ に関する実現値も同樣に求める事ができる . 


\section{$3 \cdot 2$ モンテカルロシミュレーション}

本研究では, 既知と仮定する等価弾性テンソルの実現值もしくは等価弾性定数の実現値の確率特性を得るため に , モンテカルロシミュレーションによる模擬的な数值実験を行う . 素材の材料定数のばらつきとして正規分布 を仮定するため，Box-Muller 法 ${ }^{(11)} に$ 基づき，次式を用いて正規乱数を発生させた .

$$
\alpha^{*}=\sqrt{-2 \sigma^{2} \log U_{1}^{*}} \times \sin 2 \pi U_{2}^{*}
$$

ここで $\sigma^{2}$ は確率変数 $\alpha$ の分散であり， $U_{1}^{*}$ と $U_{2}^{*}$ は $, 0<U_{1}^{*} \leq 1,0 \leq U_{2}^{*} \leq 1$ となる一樣乱数の実現値である. 乱数の生成にはメルセンヌツイスター法を用いた .また ,モンテカルロシミュレーションの試行回数は 10,000 回とした .モンテカルロシミュレーションによる確率応答, 例えば等価弾性テンソルの期待值, 分散および 変動係数は次式で計算した。

$$
\begin{aligned}
& \operatorname{Exp}\left[\boldsymbol{C}^{H^{*}}\right] \approx \frac{1}{n} \sum_{k} \boldsymbol{C}^{H^{*}}{ }_{k} \\
& \operatorname{Var}\left[\boldsymbol{C}^{H^{*}}\right] \approx \frac{1}{n} \sum_{k}\left(\boldsymbol{C}^{H^{*}}{ }_{k}-\operatorname{Exp}\left[\boldsymbol{C}^{H^{*}}\right]\right)^{2} \\
& \operatorname{CV}\left[\boldsymbol{C}^{H^{*}}\right]=\frac{\sqrt{\operatorname{Var}\left[\boldsymbol{C}^{H^{*}}\right] \mid}}{\operatorname{Exp}\left[\boldsymbol{C}^{H^{*}}\right]}
\end{aligned}
$$

ただし $n$ は試行回数，下添え字 $k$ は $k$ 番目の試行における実現値を表す .

\section{$3 \cdot 3$ 摂動法による確率均質化解析}

本報で，確率特性解析手法として摂重法を用いる.ここで素材の材料定数の実現值力试(4)と同樣に与えられ，均質化 された弾生テンソルの実現值が次式のように近似的に表現できるとする．

$$
\widehat{\boldsymbol{C}}^{H^{*}}=\boldsymbol{C}^{H 0}+\boldsymbol{C}^{H 1} \alpha^{1}+\cdots+\boldsymbol{C}^{H i} \alpha^{i}+\cdots
$$

ただし上添え字へは近似により推定された量を表し， $\alpha$ は微小な変動を仮定する．また， $C^{H i}$ は等価弾性テンソ ルの $i$ 次の摂動項を表す . 本報では, 確率特性を求める方法として, 摂動解析 ${ }^{(3)}$ により得られる摂動項と $m$ 次近 似二次モーメント法 ${ }^{(12)}$ を用い期待值及び分散を求めた . 例えば均質化された弾性テンソルの期待値 $\operatorname{Exp}\left[\boldsymbol{C}^{H^{*}}\right]$ と 分散 $\operatorname{Var}\left[\boldsymbol{C}^{H^{*}}\right]$ は次式で計算できる.

$$
\left.\begin{array}{rl}
\operatorname{Exp}\left[\boldsymbol{C}^{H^{*}}\right] \approx \operatorname{Exp}\left[\widehat{\boldsymbol{C}}^{H^{*}}\right] & =\boldsymbol{C}^{H 0}+\sum_{i_{1}} \sum_{i_{2}}\left[\boldsymbol{C}^{H 2}\right]_{i_{i_{2}}} \operatorname{cov}\left[\alpha_{i_{1}}, \alpha_{i_{2}}\right]+\cdots \\
\operatorname{Var}\left[\boldsymbol{C}^{H^{*}}\right] \approx \operatorname{Var}\left[\widehat{\boldsymbol{C}}^{H^{*}}\right] & =\sum_{i_{1}} \sum_{i_{2}}\left[\boldsymbol{C}^{H 1}\right]_{i_{1}}\left[\boldsymbol{C}^{H 1}\right]_{i_{2}} \operatorname{cov}\left[\alpha_{i_{1}}, \alpha_{i_{2}}\right] \\
& +\sum_{i_{1}} \sum_{i_{2}} \sum_{i_{3}} \sum_{i_{4}}\left[\boldsymbol{C}^{H 2}\right]_{i_{i_{2}}}\left[\boldsymbol{C}^{H 2}\right]_{i_{i_{4}}} \\
& \times\left(\mathrm{M}\left[\alpha_{i_{1}}, \alpha_{i_{2}}, \alpha_{i_{3}}, \alpha_{i_{4}}\right]-\operatorname{cov}\left[\alpha_{i_{1}}, \alpha_{i_{2}}\right] \operatorname{cov}\left[\alpha_{i_{3}}, \alpha_{i_{4}}\right]\right)+\cdots
\end{array}\right\}
$$

ただし， $\operatorname{cov}\left[\alpha_{i_{1}}, \alpha_{i_{2}}\right]$ は $\alpha_{i_{1}}, \alpha_{i_{2}}$ の共分散， $\mathrm{M}\left[\alpha_{i_{1}}, \alpha_{i_{2}}, \alpha_{i_{3}}, \alpha_{i_{4}}\right]$ は四次の確率モ一メントを表す . また , 摂動項に関する下 添え字及び $\alpha$ の下添え字は変動する物性值を表す。

\section{$3 \cdot 4$ 摂動法を用いた確率均質化逆解析手法}

本報で示す確率均質化逆解析では, 等価弾性定数(等価なヤンク率 $E^{e q}$, 等価な横弾性定数 $G^{e q}$ 及び等価なポア ソン比 $\left.v^{e q}\right)$ の期待值と分散から, 問題設定において変動すると仮定した素材の物性值(粒子のヤンク率 $E_{p}$ 及びポ 
アソン比 $v_{p}$ と樹脂のヤング率 $E_{m}$ 及びポアソン比 $\left.v_{m}\right)$ の変動係数を求める . なお , 素材の物性值の期待值は既知 とした . 本報で提案する捸動法を用いた確率均質化逆解析の流れは次の通りである .

(1)等価弾性定数の確率特性 (期待值と分散) および一次の捸動項を求め, 一次近似二次モーメント法を用いて一 次捸動法による確率均質化逆解析を行う.

(2)(1)により推定した素材の物性值の变動係数を利用して, 二次捸動法による確率均質化逆解析を行う.

$$
\text { : }
$$

(n) $n-1$ 次摂動法による確率均質化逆解析て推定した素材の物性值の変動係数を利用して, $n$ 次摂動法による確率 均質化逆解析を行う.

本計算の終了条件としては, 推定される素材の物性值の変動係数か収束した場合や, 高次捸動項の計算コスト を鑑みて適当な次数の摂動までて計算を打ち切ることが考えられる．本報では後者の観点から，3 次までの摂動 項を用いた場合の解析を行い，解析精度を調査した。

ここで, 複合材料は複数の素材から構成されるが, 素材の単一の変動を仮定できる場合と, 複数の変動を想定 する場合で具体的な計算過程が若干異なるため，各々の場合について記述する．

\section{(a)素材の単一の物性値が変動する場合}

素材の単一の物性值か変動し, 他は無視できることが明らかな場合, 例えば等価縦弾性定数の確率特性は式(11) より次式のように求められる.

$$
\left.\begin{array}{l}
\operatorname{Exp}\left[\widehat{E}^{e q^{*}}\right]=E^{e q 0}+E^{e q 2} \mathrm{CV}[\alpha]^{2}+\cdots \\
\operatorname{Var}\left[\widehat{E}^{e q^{*}}\right]=\left(E^{e q 1}\right)^{2} \mathrm{CV}[\alpha]^{2}+\left(E^{e q 2}\right)^{2} \times\left(\mathrm{M}[\alpha, \alpha, \alpha, \alpha]-\mathrm{CV}[\alpha]^{4}\right)+\cdots
\end{array}\right\}
$$

本問題設定では微視的な確率変数 $\alpha$ の変動係数 CV $[\alpha]$ が未知である一方, 式(12)における等価弾性定数の分散

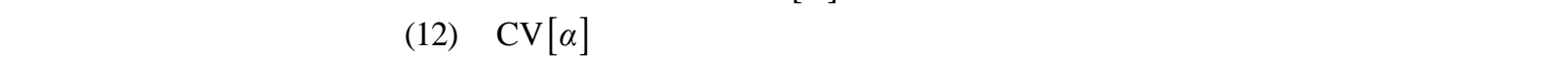

ここでまず，上述の手順(1)における一次摂動法による確率均質化逆解析では，式(12)より，容易にCV $[\alpha]$ 推 定值か計算できる . 例えば等価縦戦性定数 $E^{e q}$ の分散が既知であった場合には, 次式の通り既知の分散及び等価 弾性定数に関する一次の捸動項から CV $[\alpha]$ が得られる.

$$
\mathrm{CV}[\alpha]=\frac{\sqrt{\operatorname{Var}\left[E^{e q}\right]}}{E^{e q 1}}
$$

式(13)による推定は非常に簡便である一方, 一次摂動法による低次近似に起因する等価弾性定数の分散の推定 誤差が逆解析の精度に大きく影響する . 光こで, 引き続き高次の捸動法およびそれに基づく確率モーメントの推 定を順次適用し，確率均質化逆解析を実施する。

高次の摂動法を用いた確率均質化逆解析においては, 式(12)より導出される CV $[\alpha]$ と等価弾性定数の分散の関 係式が非線形方程式となること，また CV $[\alpha]$ が分散だけでなく期待値にも影響を及ぼすことから，解か容易に得 られない. 弚こで, 既知である等価弾性定数の期待值および分散に対する推定された等価弾性定数の期待值およ び分散の誤差を最小化する最適化問題を解くことで, 素材の物性値の変動係数を推定する . 例えば, 等価縦弾性 定数の期待值及び分散か溉知の場合を例とすると, 次の最適化問題を解くことで確率均質化逆解析を実施した .

$$
\left.\begin{array}{ll}
\text { find } & \operatorname{CV}[\alpha] \\
\text { to minimize } & F_{o b j}=\left(\frac{\operatorname{Exp}\left[\widehat{E}^{e q^{*}}\right]-\operatorname{Exp}\left[E^{e q^{*}}\right]}{\operatorname{Exp}\left[E^{e q^{*}}\right]}\right)^{2}+\left(\frac{\operatorname{Var}\left[\widehat{E}^{e q^{*}}\right]-\operatorname{Var}\left[E^{e q^{*}}\right]}{\operatorname{Var}\left[E^{e q^{*}}\right]}\right)^{2} \\
\text { s.t. } & \widehat{E}^{e q^{*}}=\sum_{i} E^{e q i} \alpha^{i}
\end{array}\right\}
$$


なお，式(14)を解くために，本研究では Broyden-Fletcher-Goldfarb-Shanno(BFGS)公式による準ニュートン法 ${ }^{(13)}$ を用い，次式に示す収束条件を満たしたとき最適解が得られたものと判定した .

$$
\frac{\left|F_{o b j}^{t}-F_{o b j}^{t-1}\right|}{F_{o b j}^{t-1}} \leq 10^{-9}
$$

ここで $F_{o b j}^{t}$ は最適化過程における $t$ 回目の最適化ステップにおける目的関数值を表す .なお , 式(12)および式(14) から明らかなように, 提案手法では逆解析のための最適化解析に要する繰り返し計算において, 確率モーメント 推定のための確率均質化解析は 1 度しか実施しない . 一方 , 既報 ${ }^{(9)}$ のモンテカルロシミュレーションを用いた方 法では, 最適化ステッフ数とモンテカルロシミュレーションの試行数に応じた回数の均質化解析が必要となるた め，特に均質化解析にコストを要する均質化法の利用を前提とした場合，提案手法は極めて効率的に逆解析か実 施できることか娳点である .

また，本手法においては，一次摂動法を用いた場合も式(14)を解くことで解が得られると考えられるが，一次 摂動法を用いた場合の解が以降の高次摂動法を用いた場合の解の探索の初期值に影響を及ぼすことから，できる 限り精確な解を得る必要があること, 一次捸動法の利用を仮定している段階では微視的な確率変数の变動係数は 全くの未知であり，探索初期值の設定が任意となることなどから，一次捸動法を用いた場合の解の推定に限り， 式(13)を用いた陽な代数形式て解を求めることとした .

\section{(b)素材の複数の物性値が変動する場合}

一般には, 複数の物性值が光れ光れ異なるばらつきを有する場合を想定する必要がある．このとき，上記のよ うに単一の等価弾性定数の確率特性から微視的な確率特性を推定するのでは無く, 変動しうる素材の弾性定数を 全てパラメータとし，測定可能な全ての等価弾性定数の確率特性から弚れらを推定する．

具体的には，本研究の場合には正方配列された粒子強化複合材料て粒子と樹脂の両者とも等方性材料を仮定す ることから, 素材の弾性定数は粒子の縦弾性定数 $E_{p}$ およびポアソン比 $v_{p}$, 樹脂の縦弾性定数 $E_{m}$ 及びポアソン比 $v_{m}$ の 4 種類となる .ここで本研究における確率均質化逆解析はマルチスケール確率応力解析を実施するための微 視的な確率変動の推定を目的としていること, 及び粒子強化複合材料においては, 上記の 4 つ素材の弾性定数 のうち粒子のポアソン比の変動か確率均質化特性やミクロ応力状態に及ぼす影響が他と比へ小さかったことから， これを除いた $E_{p}, E_{m}$ および $v_{m}$ の変動を確率均質化逆解析により推定することとした .また , 本報ではこれらの 確率変数は独立に変動すると仮定した .

ここで, (a)と同樣にまず一次摂動法を用いた場合の微視的確率変動推定について考える.式(11)より，三種類 の微視的変動を考えた場合の一次摂動法による等価弾性定数の分散は次式て計算できる.

$$
\left\{\begin{array}{l}
\operatorname{Var}\left[\widehat{E}^{e q^{*}}\right] \\
\operatorname{Var}\left[\widehat{G}^{e q^{*}}\right] \\
\operatorname{Var}\left[\hat{v}^{e q^{*}}\right]
\end{array}\right\}=\left[\begin{array}{lll}
\left.\left.E^{e q 1}\right|_{E_{p}} E^{e q 1}\right|_{E_{p}} & \left.\left.E^{e q 1}\right|_{E_{m}} E^{e q 1}\right|_{E_{m}} & \left.\left.E^{e q 1}\right|_{V_{m}} E^{e q 1}\right|_{v_{m}} \\
\left.\left.G^{e q 1}\right|_{E_{p}} G^{e q 1}\right|_{E_{p}} & \left.\left.G^{e q 1}\right|_{E_{m}} G^{e q 1}\right|_{E_{m}} & \left.\left.G^{e q 1}\right|_{V_{m}} G^{e q 1}\right|_{V_{m}} \\
\left.\left.v^{e q 1}\right|_{E_{p}} v^{e q 1}\right|_{E_{p}} & \left.\left.v^{e q 1}\right|_{E_{m}} v^{e q 1}\right|_{E_{m}} & \left.\left.v^{e q 1}\right|_{V_{m}} v^{e q 1}\right|_{V_{m}}
\end{array}\right]\left\{\begin{array}{l}
\mathrm{NSD}\left[E_{p}\right] \\
\mathrm{NSD}\left[E_{m}\right] \\
\mathrm{NSD}\left[v_{m}\right]
\end{array}\right\}
$$

ただし下添え字 $E_{p}, E_{m}$ および $v_{m}$ は変動する素材の弾性定数を表す．また $\mathrm{NSD}[\alpha]=\mathrm{CV}[\alpha]^{2}$ である.よって，式 (16)と既知である等価弾性定数の分散の二乗誤差最小化条件から，解くべき方程式として次式が得られる.

$$
\left\{\begin{array}{c}
\operatorname{Var}\left[E^{e q *}\right] \\
\operatorname{Var}\left[G^{e q *}\right] \\
\operatorname{Var}\left[v^{e q^{*}}\right]
\end{array}\right\}=\left[\begin{array}{lll}
\left.\left.E^{e q 1}\right|_{E_{p}} E^{e q 1}\right|_{E_{p}} & \left.\left.E^{e q 1}\right|_{E_{m}} E^{e q 1}\right|_{E_{m}} & \left.\left.E^{e q 1}\right|_{v_{m}} E^{e q 1}\right|_{v_{m}} \\
\left.\left.G^{e q 1}\right|_{E_{p}} G^{e q 1}\right|_{E_{p}} & \left.\left.G^{e q 1}\right|_{E_{m}} G^{e q 1}\right|_{E_{m}} & \left.\left.G^{e q 1}\right|_{v_{m}} G^{e q 1}\right|_{v_{m}} \\
\left.\left.v^{e q 1}\right|_{E_{p}} v^{e q 1}\right|_{E_{p}} & \left.\left.v^{e q 1}\right|_{E_{m}} v^{e q 1}\right|_{E_{m}} & \left.\left.v^{e q 1}\right|_{v_{m}} v^{e q 1}\right|_{v_{m}}
\end{array}\right]\left\{\begin{array}{c}
\mathrm{NSD}\left[E_{p}\right] \\
\mathrm{NSD}\left[E_{m}\right] \\
\mathrm{NSD}\left[v_{m}\right]
\end{array}\right\}
$$

ここで式(17)を解いた場合，低次近似による推定誤差に起因し，解が負となる場合がある .光こで制約として式(17) の解が 0 以上となる条件を付加するために ,Lagrange の未定乗数法 ${ }^{(14)}$ を用いた この場合 , 最小化すべき Lagrange 沉関数は次式で定義される . 


$$
L\left(\mathrm{NSD}\left[E_{p}\right], \operatorname{NSD}\left[E_{m}\right], \operatorname{NSD}\left[v_{m}\right], \lambda_{E_{m}}, \lambda_{E_{p}}, \lambda_{v_{m}}\right)=F_{o b j}+\lambda_{E_{p}} h\left(\mathrm{NSD}\left[E_{p}\right]\right)+\lambda_{E_{m}} h\left(\mathrm{NSD}\left[E_{m}\right]\right)+\lambda_{v_{m}} h\left(\mathrm{NSD}\left[v_{m}\right]\right)
$$

ただし， $h$ は制約条件を表す関数であり，

$$
h\left(\mathrm{NSD}\left[E_{p}\right]\right)=-\left(\mathrm{CV}\left[\alpha_{E_{p}}\right]\right)^{2}, h\left(\mathrm{NSD}\left[E_{m}\right]\right)=-\left(\mathrm{CV}\left[\alpha_{E_{m}}\right]\right)^{2}, h\left(\mathrm{NSD}\left[v_{m}\right]\right)=-\left(\operatorname{CV}\left[\alpha_{v_{m}}\right]\right)^{2}
$$

である . また $\lambda_{E_{m}}, \lambda_{E_{p}}, \lambda_{v_{m}}$ は Lagrange 乗数を表す .このとき , Karush-Kuhn-Tucker(KKT)条件を用いれば , 上記の 制約条件付き最適化問題の解が得られる. 例えば $E_{m}$ と $v_{m}$ の 2 種類の材料定数の変動を仮定した場合の KKT 条件 は次の通りである .

$$
\left.\begin{array}{l}
\frac{\partial L}{\partial \mathrm{NSD}\left[E_{m}\right]}=0, \quad \frac{\partial L}{\partial \mathrm{NSD}\left[v_{m}\right]}=0, \\
\lambda_{E_{m}} \geq 0, \quad \lambda_{v_{m}} \geq 0, \\
h\left(\mathrm{NSD}\left[E_{m}\right]\right) \leq 0, \quad h\left(\mathrm{NSD}\left[v_{m}\right]\right) \leq 0, \\
h\left(\mathrm{NSD}\left[E_{m}\right]\right) \lambda_{E_{m}}=0, \quad h\left(\mathrm{NSD}\left[v_{m}\right]\right) \lambda_{v_{m}}=0
\end{array}\right\}
$$

式(20)から得られる方程式を解くことにより，一次捸動法を用いた場合の微視的確率変動量か摊定できる .

高次捸動法による確率均質化逆解析では, (a)と同樣に既知である等価弾性定数の期待値と分散に対する推定さ れた等価弾性定数の期待値と分散の誤差を最小化する最適化問題を解くことで, 素材の物性値の変動係数を推定 する.解くべき最適化問題は次式で定義した .

$$
\begin{array}{ll}
\text { find } & \operatorname{CV}\left[E_{p}\right], \operatorname{CV}\left[E_{m}\right], \operatorname{CV}\left[v_{m}\right] \\
\text { to minimize } & \left.F_{o b j}=\sum_{j}\left(\frac{\operatorname{Exp}\left[\widehat{X}_{j}^{*}\right]-\operatorname{Exp}\left[X_{j}^{*}\right]}{\operatorname{Exp}\left[X_{j}^{*}\right]}\right)^{2}+\sum_{j}\left(\frac{\operatorname{Var}\left[\widehat{X}_{j}^{*}\right]-\operatorname{Var}\left[X_{j}^{*}\right]}{\operatorname{Var}\left[X_{j}^{*}\right]}\right)\right)^{2} \\
\text { s.t. } & \widehat{X}_{j}=\sum X_{j p_{1} p_{2} \cdots p_{m}} \alpha_{1}^{p_{1}} \alpha_{2}^{p_{2}} \cdots \alpha_{l}^{p_{l}} \\
& X_{j}=\left\{E^{e q}, G^{e q}, v^{e q}\right\}
\end{array}
$$

ただし $X_{j p_{1} p_{2} \cdots p_{l}}$ における下添え字 $p_{l}$ は等価弾性定数についての確率変数 $\alpha_{l}$ に関する捸動次数を表す． なお，利用した最適化手法および収束条件は(a)と同じである .

ここで,式(14)や式(21)を解く最適化過程において, 目的関数 $F_{o b j}$ の評価には等価弾性特性の分散を求める 必要がある.前報(9)ではこの計算にモンテカルロシミュレーションを用いていたため, 一回の目的関数評価 に $10^{4}$ 回程度の均質化解析が必要であったが, 提案手法では数回程度の均質化解析で斉むため, 大幅な計算 コスト削減が可能となる .

\section{4. 数値計算例}

\section{1 計算条件}

本報では，図 2 に示した粒子強化複合材料を対象とし，母材を Epoxy 樹脂，強化材を E-glass としたガラス粒 子強化複合材料を想定する .これに対し, 樹脂のヤング率 $E_{m}$ ，粒子のヤング率 $E_{p}$ ，樹脂のポアソン比 $v_{m}$ か独立 に変動する場合を考える.解析に用いた材料定数を表 1 に示す．この対象において，微視的変動（素材の弾性定 数のランダム変動) が一樣かつ周期的に生じていると仮定する.なお，有限要素解析には 8 節点ソリッド要素を 用い, ユニットセルの総節点数 1215 , 総要素数 1080 である.

Table 1 Elastic properties of each component material

\begin{tabular}{|c|c|c|}
\hline & Young's modulus [GPa] & Poisson's ratio \\
\hline E-glass & 73.0 & 0.22 \\
\hline Epoxy & 4.5 & 0.39 \\
\hline
\end{tabular}




\section{$4 \cdot 2$ 素材の単一の物性値が変動する場合}

解析例として，まず粒子もしくは樹脂の弾性定数のうち一つのみか変動すると仮定した場合について， $E_{m}, E_{p}$ 及び $v_{m}$ が光れぞれ変動した場合の確率均質化逆解析結果を示す. 正解となる素材の物性値の変動係数を 0.05 と し，既知とする等価弾性定数の分散をモンテカルロシミュレーションで算出した後，等価弾性定数の分散から提 案手法により素材の物性值の変動係数を推定する.本例では単一変動を仮定するため, 3・4(a)で示した手法を用

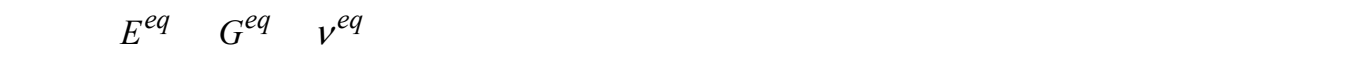

なお，提案手法の有効性を検証するために，確率均質化逆解析て推定した素材の物性値の変動係数 CVについ て，確率均質化解析に対する推定誤差 $R E_{\mathrm{CV}}$ を次式より求めた .

$$
R E_{\mathrm{CV}}=\frac{\left|\mathrm{CV}_{\mathrm{PM}}-\mathrm{CV}_{\mathrm{AS}}\right|}{\mathrm{CV}_{\mathrm{AS}}} \times 100 \quad[\%]
$$

ただし, $\mathrm{CV}_{\mathrm{AS}}$ は正解となる素材の物性値の変動係数, $\mathrm{CV}_{\mathrm{PM}}$ は提案手法を利用した確率均質化逆解析によって推 定した素材の物性値の変動係数を表す。

図 3 に, 粒子含有率 $V_{p}$ を 0.3 として $E_{m}, E_{p}$ 及び $v_{m}$ 変動を仮定した場合の等価弾性定数の変動係数, 及び逆解 析により推定された素材の弾性定数の変動係数の相対誤差を示す.まず，図 3(a)より， $E_{m}$ 変動及び $v_{m}$ 変動に対 しては等価弾性定数の変動係数が大きくなるのに対し, $E_{p}$ 変動の場合は等価弾性定数変動への影響は小さいこと が判る.次に図 3(b)より， $E_{m}$ 変動の場合，本問題設定においては，いずれの等価弾性定数の分散を用いた場合で も良好な精度でミクロ変動か推定できていることが判る.さらに, 1〜3 次までのいずれの次数を用いた場合も誤 差 $0.1 \%$ 程度の解が得られた。

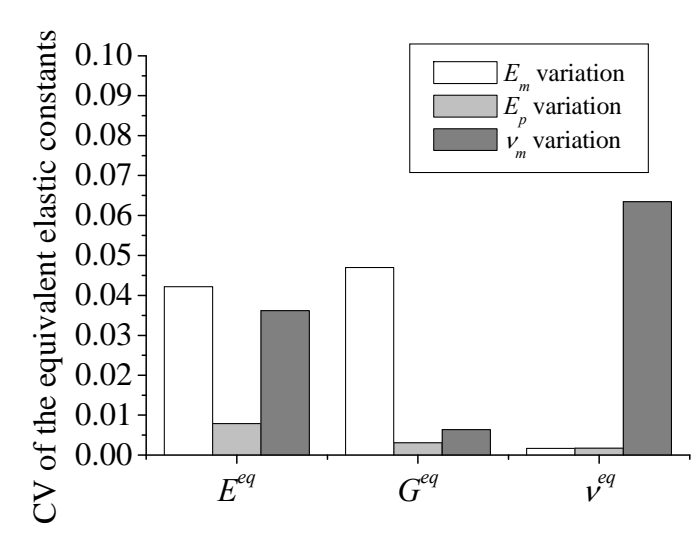

(a) CVs of the equivalent elastic properties

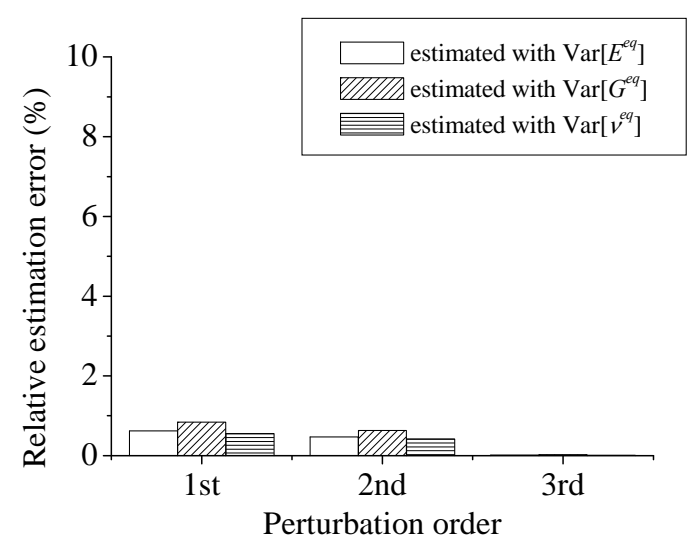

(c) $E_{p}$ variation

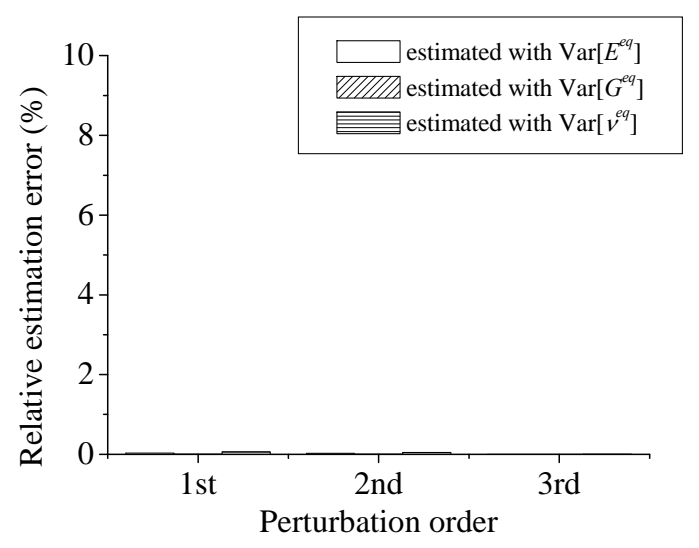

(b) $E_{m}$ variation

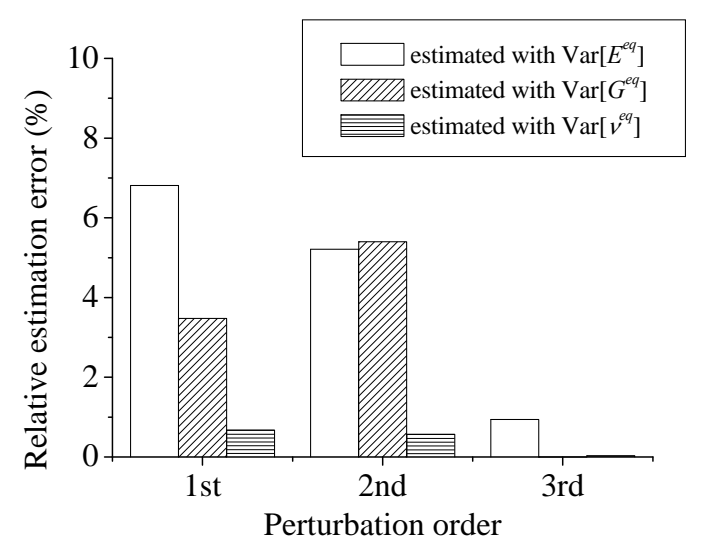

(d) $v_{m}$ variation

Fig.3 CV and relative estimation error for each microscopic random variation in the case of a single random variation $\left(V_{p}=0.3\right)$ 
$E_{p}$ 変動については, 図 3(c)よりいずれの場合でも誤差 1\%未満となっており，良好な解が得られたと考えられ るが, 等価なせん断弾性定数の分散から推定した場合は若干精度が悪い. また， 3 次捸動を用いることで，解の 精度が大幅に改善されていることか確認できる．

一方，図 3(d)より， $v_{m}$ 変動の場合は他と比較し推定精度がかなり悪いことが判る.特に 1 次および 2 次の捸動 を用い, 等価縦弾性定数もしくはせん断弾性定数の分散からミクロ変動を推定した場合, 誤差は最大 $7 \%$ 程度と 大きくなっている．また，等価なポアソン比の分散から推定した場合には誤差は $1 \%$ 程度と小さくなっている． また，3 次捸動を用いた場合には解析精度は大幅に改善しており，いずれの等価弾性定数の分散から推定した場 合でも誤差 $1 \%$ 未満と良好な結果が得られた . 一方， $v_{m}$ 変動に対し，等価なせん断弾性定数の分散と 2 次摂動を 用いて解析を行った場合，1 次摂動を用いた場合より精度が悪化している点に注意が必要である。

ここで,図3(a)に示したように $E_{p}$ 変動が等価弾性定数変動に及ぼす影響が小さいことが解析誤差の主因である 可能性を調査するために，より $E_{p}$ 変動の影響が大きくなる $V_{p}=0.5$ の場合についても解析を行った . 弚の結果を 図 4 に示す . 図 4(a)に各素材の弾性定数変動に対する等価弾性定数の変動係数, 図 4(b)に逆解析による $E_{p}$ の変動 係数の解析誤差を示す.

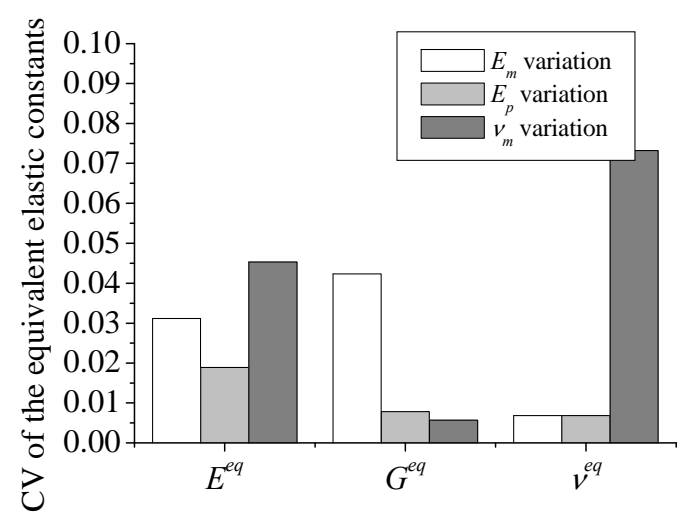

(a) CVs of the equivalent elastic properties

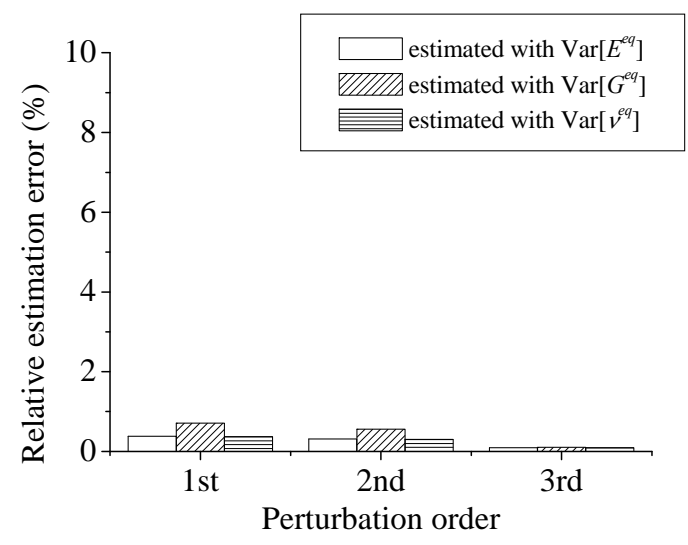

(b) Error in $\mathrm{CV}\left[E_{p}\right]$ estimation

Fig.4 $\mathrm{CV}$ and relative estimation error for each microscopic random variation in the case of a single random variation $\left(V_{p}=0.5\right)$

図 4(a)より明らかなように, $V_{p}=0.5$ の場合 , 特に粒子のヤング率か等価な縦弾性定数変動に及ぼす影響か増し ている.一方, 図 4(b)より, 例えば一次摂動により等価な縦弹性定数の変動係数を用いて解析を行った場合の誤 差は $0.2 \%$ 程度, 等価なせん断弾性定数の变動係数を用いた場合 $0.1 \%$ 程度改善しているが, $v_{m}$ の変動係数の推定 に含まれる誤差と比較すると非常に小さい.また，三次捸動を用いた場合の誤差は逆にわずかであるか増加した． これらのことから, 粒子含有率などの変化により素材の弾性定数の等価弾性定数への寄与度か変化した場合には 解析誤差に若干影響があるものの, 摂動法による確率均質化解析の精度に起因する誤差と比較すると小さいこと か確認できた .

これらの結果より，ミクロ変動の種類に応じ適切な等価弾性特性を選択するか，3 次摂動法を用いることで， 良好な精度の確率均質化逆解析か実施できると考えられる。

次に , 最も精度の悪かった $v_{m}$ 変動の場合について， $V_{p}$ を $0.1 \sim 0.5$ まで変化させた場合の $V_{p}$ と $R E_{\mathrm{CV}}$ の関係を 調査した . 1 3 次までの捸動を用いた確率均質化逆解析結果と正解との相対誤差を図 5 に示す.

図 5(a)より，粒子含有率力増加するにつれ， $v_{m}$ 変動に対する $E^{e q}$ および $v^{e q}$ の変動係数は大きくなっているこ とが判る.一方， $G^{e q}$ の変動係数は小さくなっている.これに対し図 5(b)〜(d)より， $E^{e q}$ の分散から推定した場 合は粒子含有率か増すにつれ誤差が減少している一方， $G^{e q}$ もしくは $v^{e q}$ から推定した場合には, 粒子含有率の 増加に伴い解析誤差は悪化している．このことから，等価弾性定数の変動係数の大きさ光のものと，逆解析誤差 との直接の相関は見られないことか確認できる．また，特に 1 次もしくは 2 次の摂動法を用いる場合，適切な等 価弾性定数 (本ケースでは $v^{e q}$ ) の分散を利用できれば粒子含有率の影響は比較的小さくて済むが, 不適切な等 価弾性定数 (本ケースでは $E^{e q} も し く は G^{e q}$ ) の分散をミクロ変動推定に用いる場合, 粒子含有率が逆解析の精 
度に影響を及ぼし，より良好な精度を与える等価弾性定数の種類も変化することから注意が必要である．また， 図 5 から確認できるとおり，3 次捸動法を用いた場合いずれの粒子含有率でも良好な精度を得ることができた .

以上のように, $E_{m}$ 変動もしくは $E_{p}$ 変動の場合には1 1 次捸動法でも誤差 $1 \%$ 程度以下の良好な結果が得られたが， $v_{m}$ 変動の場合には逆解析に用いる等価弾性定数の種類により３次程度の摂動法を使用する必要があるといえる． この理由としては，素材のヤング率変動と各等価弾性定数の関係か比較的線形に近く低次の摂動でも良好な近似 が得られる一方, ポアソン比変動の場合には, 特に等価縦弾性定数およびせん断弾性定数との関係か強い非線形 性を示すため，３次程度以上の摂動を用いなければ良好な近似が得られないことが考えられる．

これらの内容は, 不均質材料の確率均質化解析に関する報告(3)(4)おいても示唆されており, 本問題の解析精度の 向上のためには, 確率均質化解析手法の精度向上が有効であると考えられる .

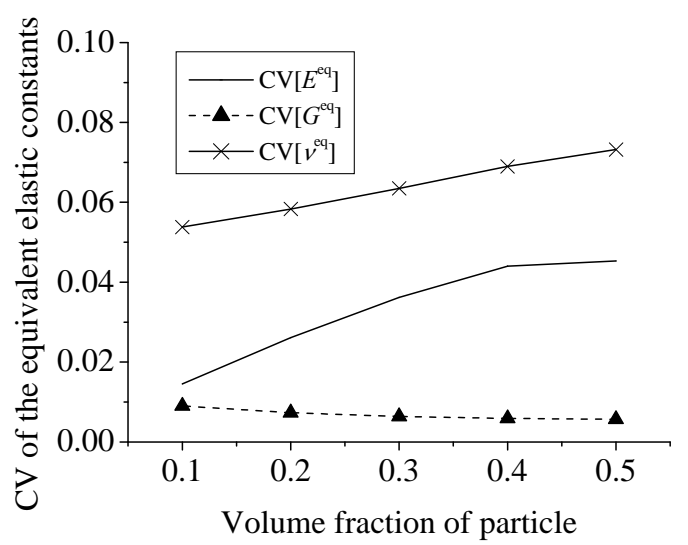

(a) estimated CVs of the equivalent elastic properties

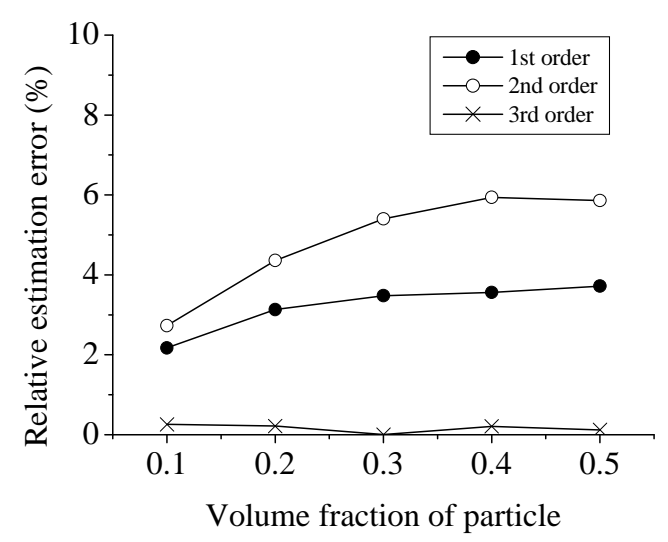

(c) estimated with $G^{e q}$

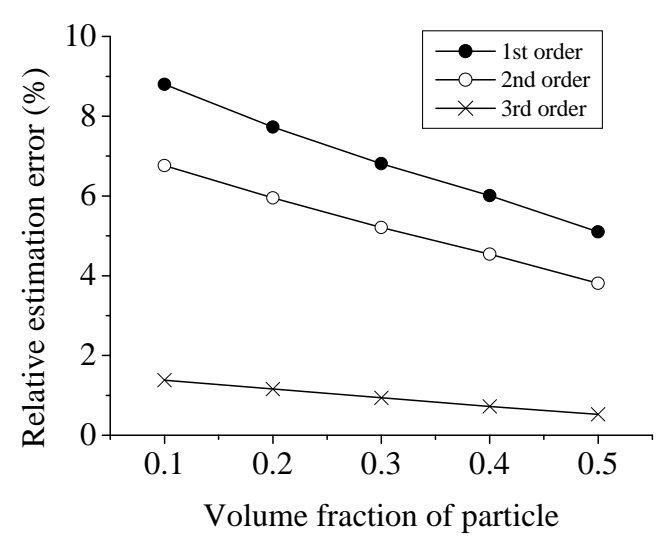

(b)estimated with $E^{e q}$

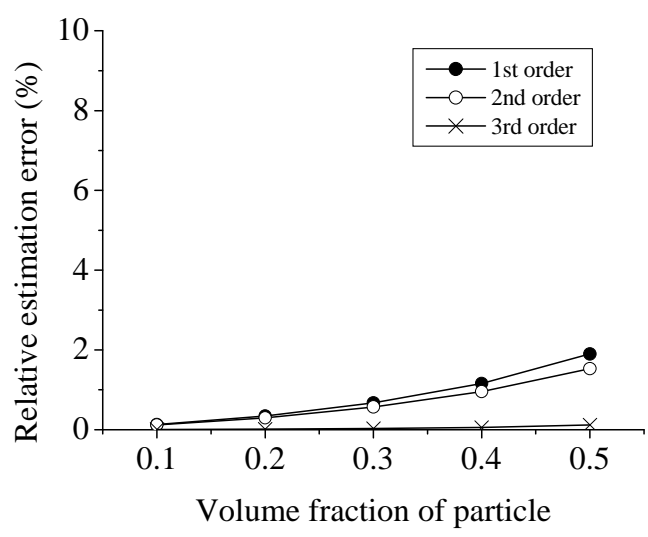

(d) estimated with $v^{e q}$

Fig.5 Relative estimation error for each $V_{p}$ and order of perturbation ( $v_{m}$ variation)

\section{$4 \cdot 3$ 素材の複数の物性值が変動した場合}

次に，素材の複数の物性值か変動する場合を考える.今回は解析例として，まず粒子含有率 $V_{p}$ が $0.3, E_{m}$ と $v_{m}$ が同時かつ独立に変動する場合を考える．この問題について，3・4(b)で示した提案手法を用いて，以下に示す素 材の物性值の変動係数の組み合わせによる確率均質化逆解析を行った .

(1) $\mathrm{CV}\left[E_{m}\right]=0.05, \mathrm{CV}\left[v_{m}\right]=0.01$ と仮定した場合

(2) $\mathrm{CV}\left[E_{m}\right]=0.01, \mathrm{CV}\left[v_{m}\right]=0.05$ と仮定した場合

(3) $\mathrm{CV}\left[E_{m}\right]=0.05, \mathrm{CV}\left[v_{m}\right]=0.05$ と仮定した場合 
図 6 に ,1〜3 次までの摂動項を用いた場合について，樹脂のヤンク率およびポアソン比に関する確率均質化逆 解析結果の誤差を示す . 図 6(a)は樹脂のヤング率の変動係数推定結果, 図 5(b)は樹脂のポアソン比の変動係数推 定結果を表す。

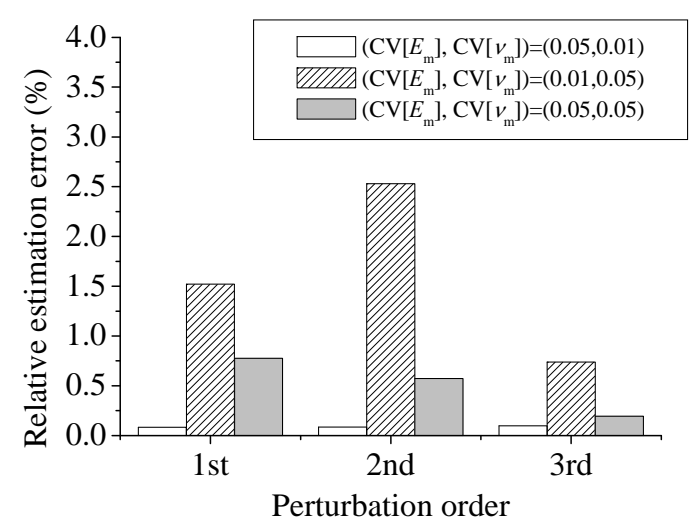

(a) error in estimated $\mathrm{CV}\left[E_{m}\right]$

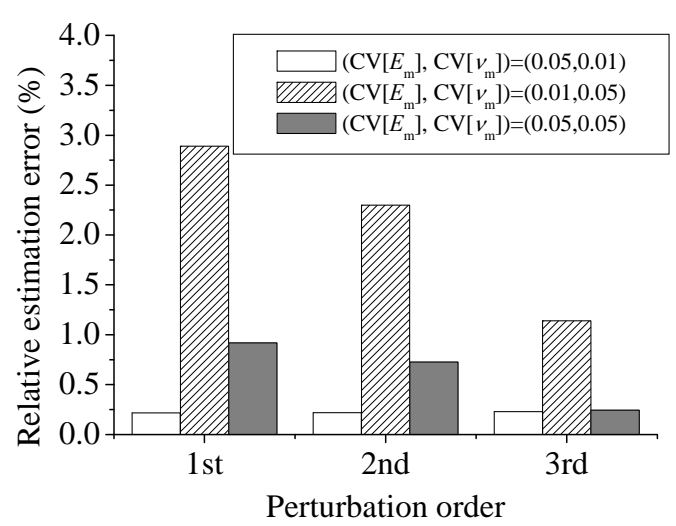

(b) error in estimated $\mathrm{CV}\left[v_{\mathrm{m}}\right]$

Fig.6 Relative error in the estimated CVs of the elastic properties of resin in the case of $E_{m}$ and $v_{\mathrm{m}}$ variations

図 6 より,樹脂のヤング率変動が大きい場合 (上記(1)および(3)) には樹脂のヤング率およびポアソン比の変動 係数のいずれもが良い精度で推定できていることか確認できる 一方,ポアソン比変動が支配的な場合(上記(2)) , 他と比較し解析誤差が大きくなっていることが判る .これは, 前節で示したとおり樹脂のポアソン比変動の場合 の逆解析精度が低いことに起因すると考えられる．しかしながら，複数変動を考慮した場合の逆解析誤差は最大 で3\%と, 単数変動を仮定した場合の最大誤差より小さい．このことから, ミク口変動推定のために適切な等価 弾性定数が選択できない場合, 本節で示した複数変動を仮定した手法を用いることで, 比較的精度の良い結果が 得られることが示唆される.

また , 3 次摂動法を用いた場合，いずれの問題設定でも解析誤差は最大 $1 \%$ 程度であつた .これより，本報にお ける問題設定に対しては，3 次以上の摂動法による確率均質化逆解析手法の有効性が高いことか確認できた .

次に, 単一変動の場合の誤差が小さかった樹脂及び粒子のヤング率変動の場合について同樣の解析を行った . 例として次の場合の解析結果を图 7 に示す。

(4) $\mathrm{CV}\left[E_{m}\right]=0.05, \mathrm{CV}\left[E_{p}\right]=0.01$ と仮定した場合

(5) $\mathrm{CV}\left[E_{m}\right]=0.01, \mathrm{CV}\left[E_{p}\right]=0.05$ と仮定した場合

(6) $\mathrm{CV}\left[E_{m}\right]=0.05, \mathrm{CV}\left[E_{p}\right]=0.05$ と仮定した場合

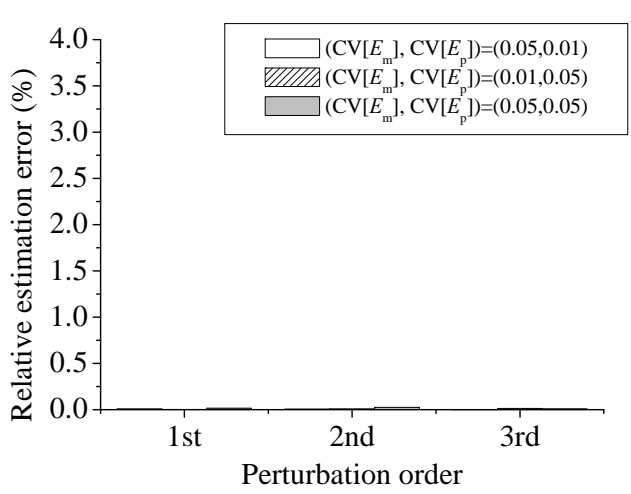

(a) error in estimated $\mathrm{CV}\left[E_{m}\right]$

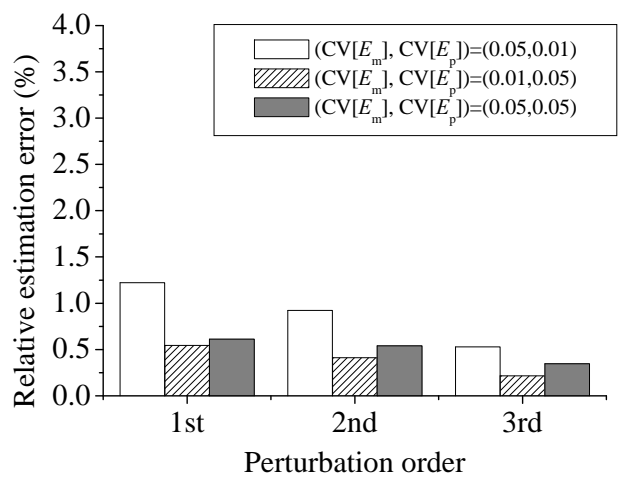

(b) error in estimated $\mathrm{CV}\left[E_{p}\right]$

Fig.7 Relative error in the estimated CVs of the elastic properties of resin in the case of $E_{m}$ and $E_{p}$ variations 
図 7 より, 粒子のヤング率変動が小さい場合 (上記(4)), 粒子のヤング率の変動係数の推定精度が若干悪い。 しかしながら，一次摂動を用いた場合でも相対誤差で約 $1.2 \%$ であり，良好な解が得られた．また，本ケースでは 樹脂のヤング率変動についてはいずれの場合でも誤差が $0.1 \%$ 未満と非常に精度の良い解が得られた .これは樹脂 のポアソン比変動を伴う場合と比べて十分解析精度が良いと言える .このことから，本問題においては，図 3(a) に示した各素材の弾性定数の等価弾性定数変動への寄与度が小さい粒子のヤング率か確率変動を有する場合でも， 良好な精度の解が得られることが判る.また, 図 3,図 6 との比較により, 本問題設定では単一変動の場合の解析 精度が複数変動においても大きく影響すると考えられる .この解析精度の悪化の原因としては, 素材の単一の物 性値か変動する場合と同樣, 摂動法による確率均質化解析 (順解析) の解析精度が大きく影響すると考えられる.

\section{5. 結 言}

本報では, 等価弾性特性解析手法として均質化法, 確率特性解析手法として摂動法を用いた確率均質化逆解析 の手法を提案し，提案手法による確率均質化逆解析を行った . 乥して , 既知と仮定したモンテカルロシミュレー ションによる確率均質化解析結果を用いて提案手法の解析精度を調査し，提案手法の有効性を評価した .

提案手法の解析精度について, 素材の単一の物性値変動を仮定した場合, 提案手法による解析誤差は， $E_{m}$ お よび $E_{p}$ 変動の場合には 1 次を含む低次の摂動法を用いた場合でも $1 \%$ 程度以下となった .一方,$v_{m}$ 変動の場合に は 1 次や 2 次の摂動法を用いた場合, 参照する等価弾性定数の変動係数の種類によっては 6 8\%程度の誤差が生 じたが，３次摂動法を用いた場合で最大 $1 \%$ 程度となった 。

また, 素材の複数の物性値変動の例として, $E_{m}$ 変動と $v_{m}$ 変動を仮定した場合および $E_{m}$ 変動と $E_{p}$ 変動を仮定 した場合について解析を行った . 前者の場合，解析誤差は 1 次摂動法を用いた場合で最大 $3 \%$ 程度 , 3 次捸動法を 用いた場合で最大 $1 \%$ 程度であった 一一方，後者の場合は 1 次摂動法を用いた場合でも最大誤差は $1 \%$ 程度であっ た . 以上より，本問題について，ヤンク率変動のみの場合には 1 次や 2 次の低次摂動法でも良好な回を得ること ができる一方，樹脂のポアソン比変動を含む場合には，3 次以上の捸動法を用いることで, 提案手法により確率 均質化逆解析が精度良く行えると考えられる .これらの解析誤差の原因としては，捸動法による近似に起因する 確率均質化解析の誤差が考えられるため, 当該問題の解析精度完全が逆問題解析精度にも繋がると予想されるた め, 今後の改善か㴗望されると考える . また , 計算コストについて, Windows7, Xeon3.2GHz の PC を用い, 単一 変動を仮定した場合を例にとると, モンテカルロシミュレーションを用いる手法では, 試行回数を 10,000 とした 場合一回の目的関数計算に約 35 時間を要したのに対し 提案手法を用いた場合は逆解析全体に要する時間が最大 約 100 秒であった .このことから，提案手法により大幅に計算効率か改善できたことか確認できた .

\section{謝辞}

本研究の一部は, 科学研究費若手研究(B) (課題番号 : 23760097, 平成 23〜26 年度) および文部科学省私立大 学戦略的研究基盤形成支援事業(平成 24 年 平成 26 年)の援助を受けた .ここに謝意を表する.

\section{文献}

(1) Kaminski M. and Kleiber M., "Stochastic structural interface defects in fiber composites", International Journal of Solid and Structures, Vol.33 (1996), pp.3035-3056.

(2) Kaminski M., "Sensitivity and randomness in homogenization of periodic fiber-reinforced composites via the response function method", International Journal of Solid and Structures, Vol.46(3-4), (2009), pp. 923-937.

(3) Sakata S., Ashida F., Kojima T. and Zako M., "Three-dimensional stochastic analysis using a perturbation-based homogenization method for homogenized elastic property of inhomogeneous material considering microscopic uncertainty", International Journal of Solid and Structures, Vol. 45(3/4), (2008), pp.894-907.

(4) Sakata S., Ashida F. and Zako M., "Kriging-based Approximate Stochastic Homogenization Analysis for Composite Material", Computer Methods in Applied Mechanics and Engineering, Vol.197(21-24), (2008), pp.1953-1964.

(5) Sakata, S. and Ashida, F., "Hierarchical stochastic homogenization analysis of a particle reinforced composite material considering non-uniform distribution of microscopic random quantities", Computational Mechanics, Vol.48, (2011), pp.529-540. 
(6) Sakata S., Ashida F., and Enya K., "Stochastic analysis of microscopic stress in fiber reinforced composites considering uncertainty in a microscopic elastic property", International Journal of Solid Mechanics and Materials Engineering, Vol.4 (2010), pp.568-577.

(7) Sakata S., Ashida F. and Enya K., "Perturbation-based stochastic analysis on microscopic stress for particle reinforced composite material considering microscopic uncertainty in material property", International Journal for Multiscale Computational Engineering, Vol.9, Issue 4, (2011), pp.395-408.

(8) Mori T. and Tanaka K., "Average stress in matrix and average elastic energy of materials with misfitting inclusions", Acta Metallurgica, Vol.21 (1973), pp.571-574.

(9) Sakata S., Ashida F., and Shimizu Y., "Inverse stochastic homogenization analysis for particle-reinforced composite material with the Monte-Carlo simulation”, International Journal of Multiscale Computational Engineering, Vol.9 (2011), pp.409-423

(10) Guedes M. and Kikuchi N., "Preprocessing and postprocessing for materials based on the homogenization method with adaptive finite element method", Computer Methods in Applied Mechanics and Engineering, Vol.83, (1990) pp.143-198.

(11) William H. Press, Saul A. Teukolsky, William T. Vetterling, Brian P. Flannery 著 丹慶勝市, 奥村晴彦, 佐藤俊郎, 小林誠 訳, NUMERICAL RECIPES in C，技術評論社 (1993), pp-216-217.

(12) 西谷章, 樫村俊也, “信頼性指標と 2 次モーメント法”, 日本建築学会 建築雑誌 Vol.114 (1999), pp.86-89.

(13) 今野浩, 山下浩, 非線形計画法, 日科技連出版社 (1978), pp.1-3, pp.127-165, pp.205-214, pp.217-220.

(14) 福田雅夫, 非線形最適化の理論, 朝倉書店 (1980), pp.56-61. 